\section{La Révolution française}

Cahiers de l'Institut d'histoire de la Révolution française

\section{$8 \mid 2015$}

Entre la Révolution et l'Empire : une nouvelle politique dans l'océan Indien

\title{
Politics in the Marketplace: The Popular Activism and Cultural Representation of the Dames des Halles during the French Revolution
}

La Politique au marché : l'activisme populaire et les représentations culturelles des Dames des Halles durant la Révolution française

Katie Jarvis

\section{OpenEdition}

\section{Journals}

Electronic version

URL: http://journals.openedition.org//rf/1313

DOI: $10.4000 /$ Irf.1313

ISSN: 2105-2557

\section{Publisher}

IHMC - Institut d'histoire moderne et contemporaine (UMR 8066)

Printed version

Date of publication: 23 June 2015

\section{Electronic reference}

Katie Jarvis, «Politics in the Marketplace: The Popular Activism and Cultural Representation of the Dames des Halles during the French Revolution », La Révolution française [Online], 8| 2015, Online since 24 June 2015, connection on 14 February 2020. URL : http://journals.openedition.org//rf/1313 ; DOI : $10.4000 /$ Irf. 1313

This text was automatically generated on 14 February 2020

(c) La Révolution française 


\section{Politics in the Marketplace: The Popular Activism and Cultural Representation of the Dames des Halles during the French Revolution}

La Politique au marché : l'activisme populaire et les représentations culturelles des Dames des Halles durant la Révolution française

Katie Jarvis

\section{EDITOR'S NOTE}

Thèse soutenue sous la direction de Suzanne DESAN, Vilas-Shinners Professor of History, University of Wisconsin-Madison le 15 mai 2014 devant un jury compose de Laird Boswell, Mary Louise Roberts, Victoria Thompson, et Anne Vila. 


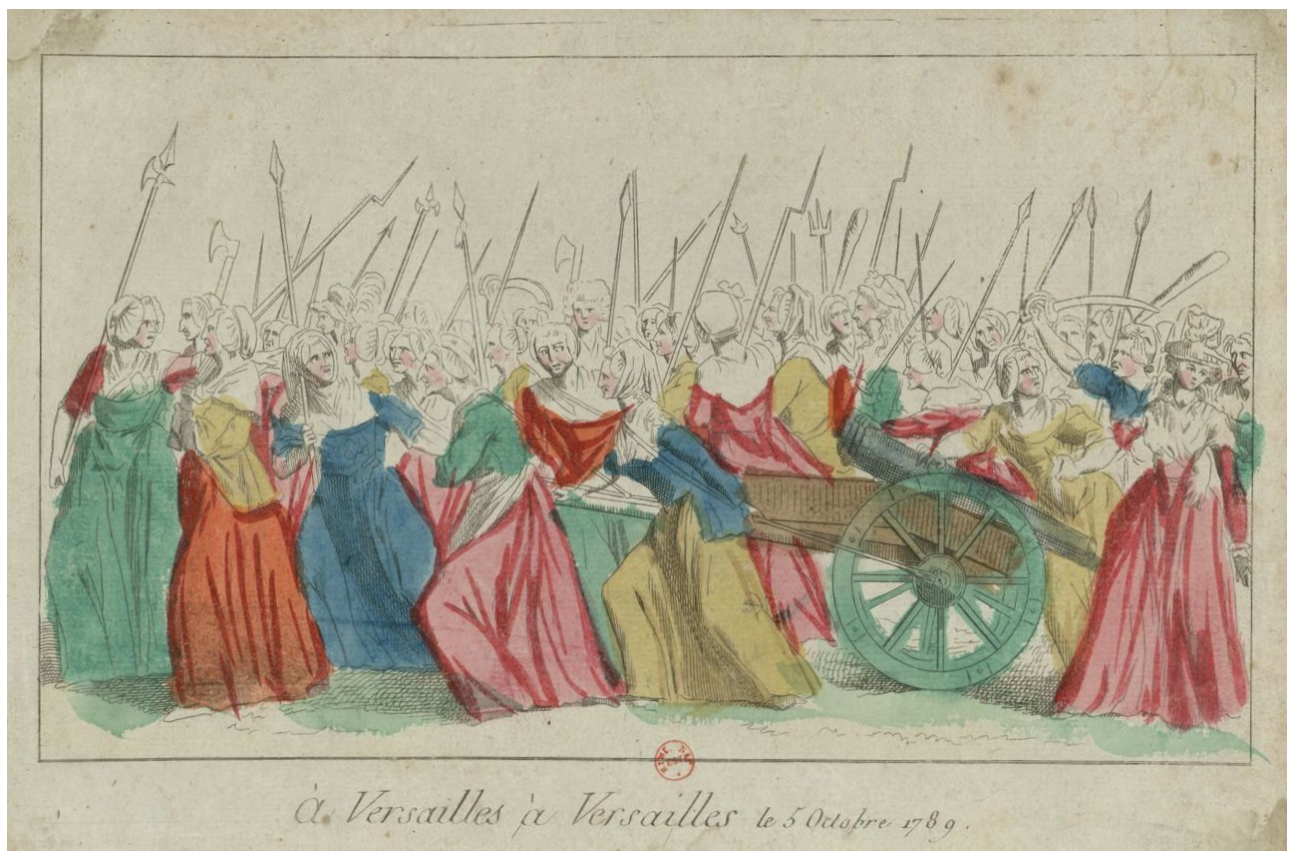

Bibliothèque nationale de France, 1789

1 Three months after French revolutionaries stormed the Bastille, Parisian market women, called the Dames des Halles, led thousands of women in a march to Versailles. After demanding bread from the king, petitioning the National Assembly, and rallying thousands of National Guards, the Dames triumphantly returned to Paris with bread and the king himself. On this and many other occasions, the market women and the marketplace drove revolutionary politics in new directions. This dissertation asks how the Dames recreated their civic identity and fraternal relations in the marketplace, while pursuing commercial interests. I argue that, among their modest stalls, the Dames negotiated the dual rise of democratic aspirations and capitalism. At the crux of this volatile transformation, they built their civic membership upon the cornerstone of useful work rather than predicate it upon gender. Consequently, this study alters our understanding of nascent citizenship at the cusp of modern democracy.

This dissertation offers a panoramic window into the Dames' world, from the calling of the Estates General in 1789 to Napoleon's coronation as emperor in 1804. It draws heavily from marketplace reports, court cases, police records, assembly debates, political pamphlets, newspapers, and visual material. To bring these diverse sources into dialogue, I read against the grain. In one direction, I dissect social sources from a cultural perspective. I examine price control legislation, court transcripts, and police reports to delineate different notions of the cooperative nation. In the opposite direction, I scrutinize cultural evidence in a social light. I reveal how commercial competition drove the content of theatrical performances that contributed to the Dames' public image.

Due to their pivotal involvement in the Parisian food trade and their ritual role as representatives of the popular classes, the Dames wielded tremendous influence. As retailers, the Dames provided practical quantities of fish, eggs, vegetables, and butter to Parisian consumers. In addition, the Dames acted as the traditional mouthpiece of the Third Estate during royal ceremonies. Literary precursors from the old Regime 
genre poissard, which portrayed the Dames in a boisterous and often hyperbolic fashion, colored how Parisians perceived the retailers in person and on the page. With the explosion of the revolutionary press, rival factions deployed the Dames' familiar image and popular legitimacy to wage pamphlet wars from 1789 to 1792 . Thus, I trace how the Dames' political clout dovetailed with their economic influence from the Revolution's earliest days.

With renewed interest in the history of capitalism, scholars have turned a post-Marxist eye back upon the Revolution. Recent studies have considered how state financial strategies, the deputies' economic philosophies, and global commerce shaped free market theory. But how did the capitalist debates in these networks permeate relationships in the street? Or how did relationships of the street permeate these capitalist imaginings? Although the Dames' modest stalls were far from the polished salons of economic debate, they demonstrate just how far the ideas of economists and philosophers infiltrated the general population or were perhaps informed by it. Even at the start of the Revolution, these theoretical discourses were deeply entangled with everyday practice. This dissertation analyzes how, through their daily trade, the Dames negotiated the tenuous juncture of capitalism and democracy with striking dexterity.

When the deputies liberated the marketplace from the shackles of corporate privilege and old Regime regulations, they threw centuries of commercial and social relationships into disarray. I inquire how the Dames and their neighbors created their own vision of revolutionary ideals while struggling with the effects of drastic reform. As indigent retailers, the Dames teetered at the intersection of corporate privilege and democratic desires. The former gave them special permission to use the market; the latter gave them substantial political legitimacy to make demands on the state. On the one hand, the Dames' own livelihood depended on charitable exceptions and free market proponents condemned these welfare measures. On the other hand, the Dames selectively deployed free market principles to rail against rivals' commercial privileges. During the birth pangs of capitalist experiments, the Dames oscillated between the moral economy dependent on local circumstances and a liberated market ensconced in national standards.

6 This study maintains that the Dames staked out their place in the regenerated public as they sold from the public earth of les Halles. To defend their trading places and their access to crucial shelters, the retailers pursued new practices of citizenship. They petitioned the municipal government and brought suits before the revolutionary justices of the peace. They seized the novel language of citizenship to mark the earth as national property, to lambast monopoly-holders as privileged leeches, to appeal to the state's paternal duties, and to secure exceptions based on their public utility as retailers. In short, the Dames began to shape their place in the body politic as they justified their personal profit on public space.

7 I also examine how currency problems spurred market actors to create innovative alliances across former corporate boundaries. After the deputies overhauled the currency system during the winter of 1789-1790, the Dames, their suppliers, their clients, and other merchants relied on unofficial money for everyday trade. I demonstrate how, to defend shared cash, Parisians formed new socio-economic associations on the ground while the deputies legally dismantled the corporate world from above. Vegetable merchants aligned with carpenters to demand new denominations, retailers joined forces with brokers to protect common promissory 
notes, and clients and merchants rallied to support overlapping lines of credit. On this new scaffolding, the Dames and their allies spurred the state to guarantee the monetary networks of its productive, and therefore most sovereign, group of citizens.

Using twin crises of food and finance, I investigate how the Dames projected their marketplace utility beyond les Halles. I argue that the police, legislators, and judges collaborated in inventing the Dames' political role while codifying their occupation. Notably, price controls called the Maximum threatened to bankrupt the Dames in 1793. The retailers protested that they traded fairly and provided crucial services among interdependent citizens. In place of pro-consumer price controls, the Dames and market police advocated for a cooperative system that balanced separate ceilings for wholesale trade, retail trade, and daily wages. During the Directory, the Dames legally integrated their trade within the body politic by purchasing commercial licenses called the Patente. These occupational taxes gave the Dames personal fiscal contracts with the state. Strikingly, the Patente cast the Dames as independent workers unlike all male wage laborers. Thus, the Dames' work gave them legal, commercial, and cultural autonomy, which the revolutionaries viewed as the ideological prerequisite for free choice and full civic membership.

Rather than assume a modern notion of democratic citizenship, I ask how the Dames and fellow revolutionaries invented multiple ideas of citizenship in its embryonic stages. In particular, my analysis intervenes in the contested historiography of gender and democratic citizenship in two crucial ways. First, it insists on exploring the numerous and potentially contradictory ways the revolutionaries invented citizenship from the outset. If we only consider the institutional attributes of citizenship, such as the right to vote, to bear arms, or to participate in political clubs, we project our current definitions back upon the revolutionary model. In doing so, we miss the opportunity to probe the myriad ways the revolutionaries conceptualized citizenship in its earliest moments. Many of these notions of citizenship challenged its legal gendered divisions. In the case of the market women, the Dames considered useful occupational work to cut across gendered boundaries and form a crucial component of citizenship.

Second, my work cuts a new pathway in current scholarship by decentering gender in the formula of citizenship. As long as we use gender as the question of socio-cultural differentiation, we can only arrive at gender as the answer for political delineation. Thus, if we are to glean perspectives on citizenship in which gender is not primary, we must step away from gender as our principal vantage point. In order to understand how historical actors invented citizenship from other angles besides gender, we cannot immediately cast them as "male" or "female" citizens. We must allow other vectors to assume the driver's seat, ask how situational realities change the principal pillars of citizenship, and then inquire where gender fits into this dynamic matrix of political identity. The Dames des Halles allow us to explore how individuals socially and economically integrated themselves into the body politic; how malleable ideas of gender played into their notion of citizenship; and how individuals continually adjusted the balance.

11 I argue that the Dames rooted their citizenship in work that served society. They imagined this useful work as the sum of three parts: occupational labor, patriotic work, and gendered work. Therefore, I examine how the Dames portrayed their political activism as a second pillar of civic membership. I trace how the Dames reconceptualized their old Regime role as representatives of the popular classes and 
interacted with revolutionary political institutions. The Dames framed their sporadic interventions as a civic duty, though self-interested. In return, they demanded the state fulfill paternal duties towards its working citizens. Whether seeking aid in subsistence crises, sanctioning the deputies' constitutional reforms, or shunning the king after his flight, the market women's public displays or powerful silences sent searing political messages.

This dissertation also analyzes how the Dames spotlighted their gendered work as a third axis of citizenship. If the Dames were the symbolic daughters of old Regime charity, they offered hope as republican mothers for the nation. They compelled the government to support the wives of soldiers, defended prisoners who missed wet-nurse payments, and spanked counterrevolutionary nuns who miseducated their children. They routinely presented themselves as female defenders of their community. Yet, the market women embraced gendered work as component of their citizenship without restricting their citizenship to gendered roles.

Consequently, I contend that the Dames des Halles remained unfazed by the male definition of legal citizenship in 1793 because the Dames did not base their sovereignty on primarily gendered or institutional scaffolding. For the Dames, citizenship was not a static concept. They constantly justified why their demands merited attention, sometimes as sovereign citizens, but never as a priori citizens by default. The Dames rarely appealed to universal, inalienable, or innate individual rights that we associate with modern citizenship. For the Dames, only the old Regime held totalizing categories of arbitrary privilege. Instead, they viewed revolutionary citizenship as contingent and temporal. Individuals joined the body politic through work that served society. In other words, the Dames viewed citizenship as a set of societally useful practices that validated one's inclusion in the body politic. And this membership legitimated one's right to make demands on the state in return. While this definition of earned citizenship was empowering for the popular classes in 1789, it became dangerously restrictive in the wake of the Terror.

As the revolutionaries gradually vested new political institutions with representative powers, they challenged the Dames' identity as the most compelling voice of the people. During this transition, written and visual depictions of the Dames reinforced and undermined their legitimacy in powerful ways. From 1794 to 1803, theatre directors strutted fictional Dames across the stage to entice spectators in ticket battles. By scrutinizing box office listings, juxtaposing printed reactions, and tracking intertextual plotlines, I dissect how Parisian playwrights and spectators engaged in commercial and artistic dialogue to construct the Dames' theatrical counterparts. Amidst quick changes of fortune during the Directory, blockbuster plays featured social-climbing Dames who rose financially but languished culturally. I illustrate how, in the playhouses, the Dames became a dynamic vessel for confronting the disquiet caused by social mobility and its corresponding political fallout.

Although the theatrical Dames lacked bourgeois cultural refinement, their occupational labor continually redeemed them across plotlines. This unwavering consistency from the outbreak of the Revolution to the crowning of Napoleon suggests that, regardless of cultural ambiguities, a broad swath of revolutionaries considered work to be the primary duty of the popular classes. However, the French continued to contest what the popular classes should gain in return for their service. Like a cart caught in the mud of les Halles, Parisians remained mired in the vexing questions of 1789: What did it 
mean to be a member of the nation? And how would this nation define popular citizenship?

The Dames des Halles occupied the epicenter of revolutionary politics because they spoke to its most fundamental, complex, and often contradictory issues. Rather than presenting us with a neat, comprehensive vision of the regenerated body politic, the retailers illustrate how the revolutionaries forged a path to citizenship around unforeseen obstacles. Their mutable goals changed as they remade politics and economics through daily trade. However, this dissertation contends that the Dames' logic of citizenship remained constant: individuals earned membership, and thus the right to make demands on the state, through useful work. The Dames included gendered duties as a pillar of citizenship, but did not posit gender as its cornerstone. In regard to European democracy, the Dames challenge us to move beyond the binary in which gender acts as the initial instrument for political differentiation. Analyses that, at the sweep of the deputies' gavel, divide individuals into rigid, gendered categories undercut the revolutionaries' complex socio-political imaginings. From the heart of les Halles, the Dames can nuance our understanding of work and nascent citizenship.

\section{INDEX}

Mots-clés: Révolution française, Dames des Halles, politique, genre, travail, citoyenneté, marché, Paris, classes populaires, rapports socio-économiques, démocratie, capitalisme, représentations culturelles

Keywords: French Revolution, Dames des Halles, politics, gender, work, citizenship, markets, Paris, popular classes, socio-economic relationships, democracy, capitalism, cultural representations

\section{AUTHOR}

\section{KATIE JARVIS}

Assistant Professor of History

Baylor University 